\title{
sciendo
}

CIVIL AND ENVIRONMENTAL ENGINEERING REPORTS

E-ISSN 2450-8594

CEER 2018; 28 (3): 155-165

DOI: $10.2478 /$ ceer-2018-0043

Original Research Article

\section{LOW-EMISSION ECONOMY \\ - EVOLUTION OR NECESSITY}

\author{
Karolina Godzisz ${ }^{1}$ \\ University of Zielona Góra, Poland
}

\begin{abstract}
A low carbon economy serves to provide economic, social and environmental benefits from measures to reduce emissions of pollutants. The implementation of a low carbon economy in Poland results from the need to reduce emissions of greenhouse gases and other air pollutants while reducing the share of coal in energy production, introducing innovative technologies and improving energy efficiency as well as increasing the standard of living of the society. This is a difficult task due to the large use of coal in energy production. The article describes the goals of creating Low Carbon Economy Plans by local government units at the local level and their use in applying for financial resources in the financial perspective 2014-2020.
\end{abstract}

Keywords: low carbon economy, plans for low-emission economy

\section{INTRODUCTION}

Economic development concerns, on the one hand, quantitative changes in the adopted economic measure (most often it is GDP) and qualitative type conditions in which economic growth takes place [19]. Qualitative issues concern many dimensions related to, among others an improvement in wellbeing, the standard of living of the majority of society, ensuring economic security and a promising future. The range of impact factors is greater when we

\footnotetext{
${ }^{1}$ Corresponding author: University of Zielona Góra, ul. Licealna 9, 65-417 Zielona Góra, e-mail, k.godzisz@iis.uz.zgora.pl
} 
consider sustainable development. In this case, it is necessary to ensure a higher standard of living for the whole society, while preserving natural resources and minimizing the impact on the natural environment (the resource exploitation rate cannot exceed the rate of its regeneration).

The sustainability criteria have been defined by the European Union. Particular emphasis has been put on reducing greenhouse gas emissions, increasing the efficiency of energy use, growth in the share of energy from renewable sources, preserving biodiversity, and increasing the use of degraded and polluted land $[8,12]$.

In the context of sustainable economic development, high importance is assigned (eg by the EU) to a low carbon economy, because it brings "profit to investors, economic growth in the country and a significant reduction in $\mathrm{CO}_{2}$ emissions" [31]. Low emission is the emission of harmful dust and gases at low altitude. In this case it is about emitters (chimneys and other emission sources) at an altitude of no more than $40 \mathrm{~m}$. However, they are usually on a ceiling of up to 10 meters. The pollutants introduced into the air at this altitude accumulate around the place of occurrence causing damage locally (usually these are places of dense residential development [29]. The term "low carbon economy" is associated primarily with energy efficiency, a significant share of renewable energy sources and reduction of emissions of harmful dusts and gases. In this case, integration of all aspects of the economy around low carbon technologies, more efficient energy solutions, "clean" energy and pro-ecological technological innovations. It is therefore associated with:

- development of low-emission energy sources;

- improvement of energy efficiency and management of raw materials and materials;

- development and use of low carbon technologies;

- improving the efficiency of waste management;

- promotion of new consumption patterns.

The overarching level of the EU and the smart policy of implementing low carbon economy at the national level is relative [2]. A suitable low carbon policy should stimulate society to take action to achieve the benefits of improving the environment [3].

\section{LOW CARBON ECONOMY IN POLAND}

The problem of low emissions in many cities around the world has been significantly reduced. In Poland, however, it seems difficult to solve. Local and national authorities often do not want to take unpopular decisions that can significantly reduce harmful emissions. These decisions are unfortunately connected with incurring higher costs for society [9]. 
In reference to international commitments regarding reduction of greenhouse gases to which Poland has obliged itself by ratifying the Kyoto Protocol established at the forum of the United Nations Framework Convention on Climate Change [23] and the Climate and Energy Package until 2020, it is necessary to take decisive actions contributing to the reduction of the emissivity of individual sectors of the economy.

The main goals of this protocol are "Achieving the goals 20/20/20":

- reduction of greenhouse gas emissions by $20 \%$ in 2020 in relation to emissions from 1990;

- increasing the share of energy from renewable sources to $20 \%$ in 2020 in the EU energy balance (for Poland 15\%);

- raising energy efficiency by $20 \%$ by 2020 .

Due to EU obligations to which Poland is subject [10,11,13-17] and the importance it can have for the level of sustainable development, the state wants to build a low-carbon economy. In the Constitution of the Republic of Poland (Article 5), it was stated that the Republic of Poland "ensures environmental protection, guided by the principle of sustainable development" [4]. The two concepts are of paramount importance, i.e. they are enshrined in the act on environmental protection [1] and in the Strategy for Sustainable Development of Poland [26]. The act assumes that sustainable development concerns socioeconomic changes allowing for the maintenance of balance in nature and ensure the continuation of basic natural processes to preserve them for future generations. The Sustainable Development Strategy of Poland states, however, that "sustainable" means "a model of development in which satisfying current social needs and the needs of future generations will be treated equally..." and "... will combine, in a harmonious way, care for the preservation of natural and cultural heritage of the nation, with civilizational and economic progress, being the contribution of all social groups" [26].

Therefore the Guidelines for the National Program for the Development of Lowcarbon Economy [25] were first developed, followed by the National Program for the Development of Low-carbon Economy [24]. They set the Low-carbon Economy as the basis for the development of the region. The main directions of activities are to lead to the creation of a low-carbon economy in the shortest possible period. The essence of the program is to provide socio-economic benefits through the use of activities related to carbon efficiency.

Realizing that the country's economic development also depends on local activities, the government has obliged local government units to prepare and implement local low carbon economy plans that refer to the National Program for the Development of Low Carbon Economy. Local Government Units should use these plans to create the basis for long-term development in their territory [20]. 
A low carbon economy means a transition to a completely new reality, especially in Poland, where the use of fossil fuels, which is the main source of greenhouse gas emissions, is widely used. It is a difficult task to make a quick jump and transform our economy into a low carbon one. Poland must take climate and emission challenges in the organizational, legal, management and, above all, technological fields. There is no possibility of disregarding what is happening in the European energy sector. In addition to organizational and legal, economic, financial and technical conditions as well as effective monitoring, there remains the issue of social awareness and proper behavior, especially in the area of low emission generated by dispersed housing. Assuming that organizational, legal, regulatory and financial problems are implemented as needed and as far as possible, structural changes and technical factors (innovation and technical progress) are the basic determinants of low carbon economy development. Overcoming the technical barriers to the development of a low carbon economy requires the absolute orientation of Polish start-ups and innovations on the broadly understood energy, transport and smart cities, ecological municipalities, or closed circuit ones. A particular role in the field of innovation must be taken by energy companies as well as industries, construction and transport related to energy or energy-intensive. A low carbon economy is also a great challenge and plenty of difficult tasks for local selfgovernments. The European and global energy revolution does not give energy companies, industry and local governments the chance to survive in their current state. It is necessary to escape forwards - a technological change of a great depth and directing the energy towards the innovative path. In Polish conditions, technical progress cannot be limited to increasing the number of gas connections, renewable energy sources and improving energy efficiency, but there is also a necessity to consider environmentally friendly use of coal in the short and medium term. There are various expectations regarding technical methods of reaching a low carbon economy, and at the same time their level of technological advancement differs [21]. 


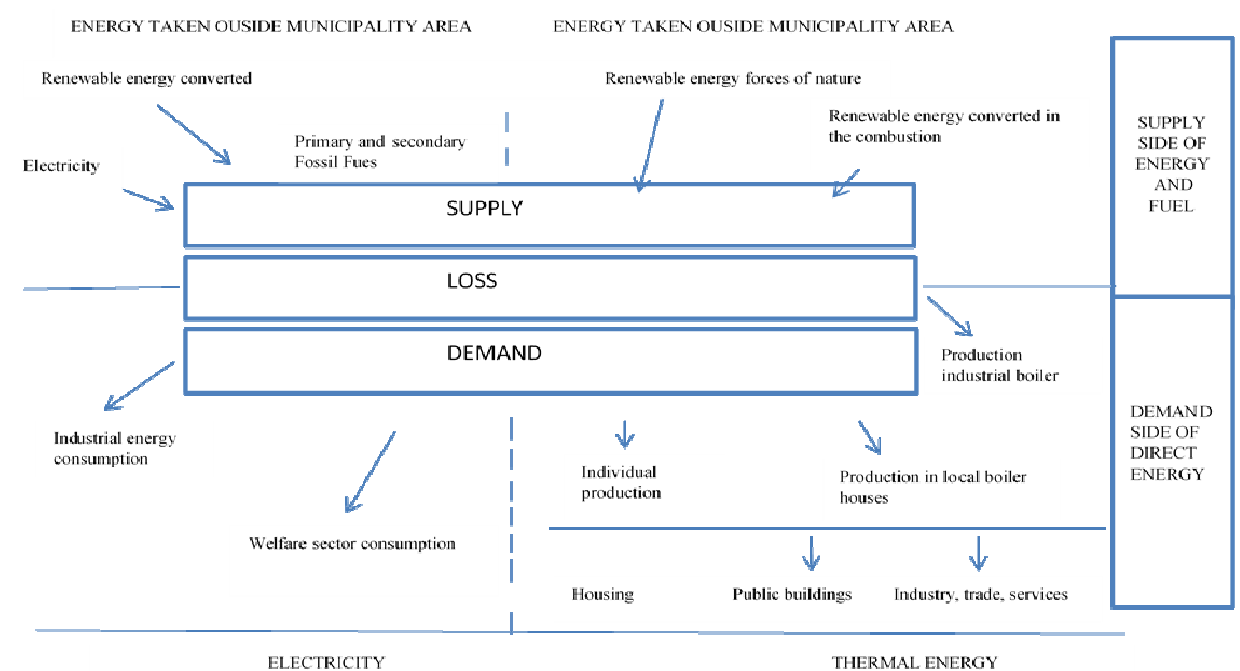

Fig. 1 Energy management by the local government [22]

Decarbonisation and low carbon economy in the electricity sector include the abandonment of combustion for natural gas, the production of electricity from renewable energy sources, $\mathrm{CO} 2$ reduction technologies and the improvement of energy efficiency in energy generation and distribution.

Economic development takes place at the local level, therefore - in order to transform the economy - appropriate actions should be planned there. In 2013, the Ministry of Economy set out the concept of preparing Local Low Carbon Economy Plans, referring to the National Program for the Development of Low Carbon Economy. Local Government Units. Local Low Carbon Economy Plans is a strategic document whose purpose is to define a vision of the development of a municipality (or several municipalities) towards a low carbon economy. Its key element is the setting of strategic and detailed goals, implementing a specific vision of the municipality. They should be specifically defined, measurable, ambitious, realistic and time-bound. The main objective of Local Low Carbon Economy Plans is to reduce emissions and it must be clearly and measurably defined (in relative or absolute form). The plan also has to determine how the municipality will achieve its goals. Therefore, it is necessary to describe the scheduled (investment and non-investment) activities, the method of financing them and the method of monitoring the implementation of the schedule in the subsequent years (at least for the period 2014-2020, with the possibility of extending the time perspective). The basis for developing a good plan is to make a reliable inventory of greenhouse gas emissions from the area of the municipality, based on its energy balance. It should include public and 
residential buildings, transport, waste management as well as industry and services. Based on the identified possibilities, actions implementing the set goals should be planned. They must be based on already existing plans and strategies. Measures to achieve goals, sources of financing and implementation, monitoring and verification plans should be indicated for scheduled activities. The prepared draft document should be subjected to the procedure of strategic environmental assessment [18].

Having a Low Carbon Economy Plan is also a prerequisite for applying for cofinancing investments for eco-energy projects in the field of low carbon economy and sustainable energy. Low carbon economy plans are supposed to contribute to achieving the goals set in the climate and energy package by 2020 :

- reduction of greenhouse gas emissions;

- increasing the share of energy from renewable sources;

- increasing energy efficiency;

- improving air quality.

Thanks to the development of Low Carbon Economy Plan, the municipality will gain:

- access to national and EU funds for co-financing investments related to atmosphere protection, energy efficiency and RES in the years 2016-2020;

- savings in the municipality budget;

- improvement of air quality in the municipality.

International programs and framework programs are instruments for the implementation of the energy policy of the European Commission. The programs are aimed at increasing energy efficiency and taking advantage of renewable energy sources. They will contribute to ensuring sustainable, competitive and secure energy for Europe and Poland. Subsidized projects can also be targeted at the promotion and dissemination of the best low emission techniques, processes, products and practices [27].

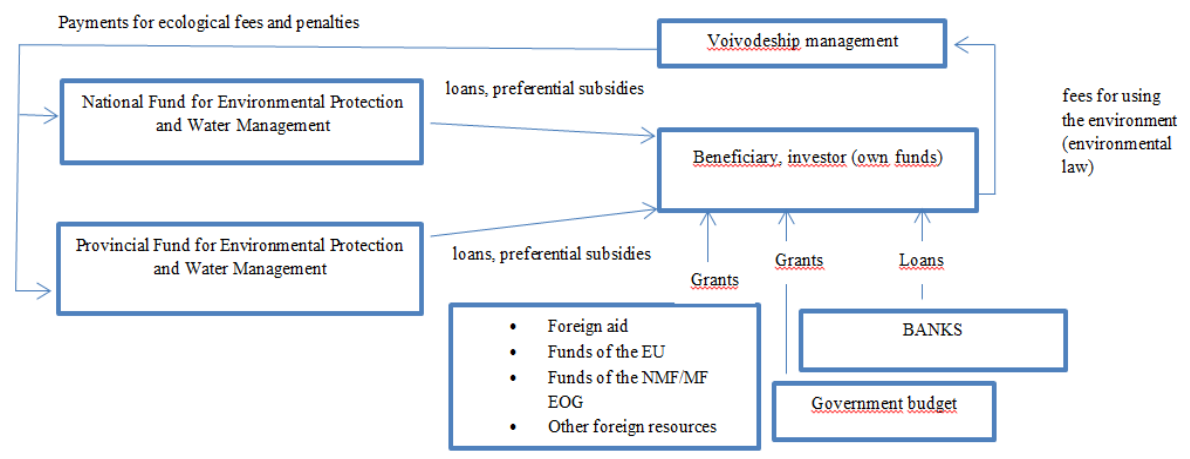

Fig. 2 Scheme of the system and main sources of financing environmental protection in Poland [30] 
The process of improving economic mechanisms in environmental protection focuses on two issues:

- developing new mechanisms meeting EU requirements and

- striving to ensure that the proposed mechanisms meet the criteria of economic efficiency, in particular financial ones [28].

The development of the Low Carbon Economy Program opens up a wide range of benefits to the municipality.

\section{LOW CARBON ECONOMY AS PART OF THE REGIONAL OPERATIONAL PROGRAMS OF THE LOWER SILESIA, LUBUSZ AND WEST POMERANIA VOIVODESHIPS IN THE YEARS 2014-2020}

The Regional Operational Program is the tool for the implementation of cohesion policy in the Lubusz voivodeship in the EU's financial perspective 2014-2020. It is a two-funded program, combining the intervention of the European Social Fund and the European Regional Development Fund. As part of the Regional Operational Program, 718.063.724 Euro was allocated as part of the Priority Axis Low Carbon Economy in the Lower Silesia, Lubusz and West Pomerania voivodeships. The support covers projects in the amount of max. $85 \%$ co-financing of the total eligible costs. The main beneficiaries are:

- entrepreneurs (microenterprises, small and medium enterprises) only in the formula of public-private partnership;

- local government units (LGUs) their unions, associations and agreements;

- organizational units of local government units with legal personality;

- commercial law companies owned by local government units;

- public and non-public healthcare facilities;

- culture institutions;

- other units of the public finance sector.

The main goals of the Priority Axis Low Carbon Economy are:

- increasing the share of RES (Renewable Energy Sources) production supporting the production and distribution of energy from RES;

- increasing the energy efficiency of buildings in the public and residential sector;

- supporting energy efficiency, intelligent energy management and the use of renewable energy sources in public infrastructure, including public buildings and the housing sector;

- reduction of low emission of pollutants from the transport sector and outflow of passengers in public transport;

- promoting sustainable multimodal urban mobility and adaptive actions that mitigate climate change; 
- increasing the share of energy generated in cogeneration - using highefficiency cogeneration of heat and electricity based on the demand for useful heat.

Table 1. Co-financing planned under OSI Low-carbon economy in 2014-2020 in the Lower Silesia, Lubusz and West Pomerania voivodships [own elaboration based on 5-7]

\begin{tabular}{|c|c|c|c|c|}
\hline Lp. & Voivodeship & $\begin{array}{l}\text { Co-financing } \\
\text { low-carbon } \\
\text { economy } \\
\text { (in EURO } € \text { ) }\end{array}$ & In & In, $\%$ \\
\hline \multirow[t]{5}{*}{1} & \multirow{5}{*}{ Lower Silesia } & \multirow{5}{*}{392.347 .048} & $\begin{array}{l}\text { Production and distribution of energy } \\
\text { from renewable sources }\end{array}$ & 14.17 \\
\hline & & & $\begin{array}{l}\text { Energy efficiency in Small Medium } \\
\text { Enterprises }\end{array}$ & 8.26 \\
\hline & & & $\begin{array}{l}\text { Energy efficiency in public utility } \\
\text { buildings and the housing sector }\end{array}$ & 38.62 \\
\hline & & & $\begin{array}{l}\text { Implementation of low-emission } \\
\text { strategies }\end{array}$ & 35.12 \\
\hline & & & High-efficiency cogeneration & 3.83 \\
\hline \multirow[t]{4}{*}{2} & \multirow{4}{*}{ Lubusz } & \multirow{4}{*}{108.005 .260} & Renewable energy sources & 16.02 \\
\hline & & & Energetic efficiency & 47.16 \\
\hline & & & Reducing low emissions in cities & 33.46 \\
\hline & & & cogeneration & 3.34 \\
\hline \multirow[t]{10}{*}{3} & \multirow{10}{*}{$\begin{array}{c}\text { West } \\
\text { Pomerania }\end{array}$} & \multirow{10}{*}{217711416} & Balanced multimodal urban mobility & 45.93 \\
\hline & & & Energy modernization of public facilities & 4.73 \\
\hline & & & $\begin{array}{l}\text { Energy modernization of public facilities } \\
\text { as part of the ZIT strategy for the } \\
\text { Szczecin Metropolitan Area }\end{array}$ & 4.59 \\
\hline & & & $\begin{array}{l}\text { Energy modernization of multi-family } \\
\text { housing buildings }\end{array}$ & 5.87 \\
\hline & & & $\begin{array}{l}\text { Energy modernization of multi-family } \\
\text { housing buildings as part of the ZIT } \\
\text { strategy for the Szczecin Metropolitan } \\
\text { Area }\end{array}$ & 2.3 \\
\hline & & & $\begin{array}{l}\text { Replacement of conventional energy } \\
\text { sources with renewable sources }\end{array}$ & 1.84 \\
\hline & & & $\begin{array}{l}\text { Increased use of renewable energy } \\
\text { sources }\end{array}$ & 28.54 \\
\hline & & & $\begin{array}{l}\text { Increasing the potential of the energy } \\
\text { network to receive energy from } \\
\text { renewable energy sources }\end{array}$ & 0.46 \\
\hline & & & $\begin{array}{l}\text { The development of cogeneration energy } \\
\text { sources }\end{array}$ & 4.60 \\
\hline & & & $\begin{array}{l}\text { Energy modernization of public utilities } \\
\text { of the voivodship self-government }\end{array}$ & 1.14 \\
\hline
\end{tabular}


The amount of financial resources allocated to activities related to the creation of low carbon economy affects the scale of investments undertaken in this field and determines the quality of the natural environment in a given region. The system of financing environmental protection in Poland can be considered as extensive, however, there are still too few funds for environmental measures in relation to needs and commitments. Therefore, with a view to the next programming, Poland should focus today not only on the risks affecting the rate and level of use of aid funds, but also on the directions of their spending and the quality of subsidized projects. It is necessary to improve the institutional system and the procedures for applying for funds, implementing and controlling projects.

\section{CONCLUSIONS}

The problem of reducing low energy efficiency has not yet been solved. It is the cause of many negative economic and social consequences. One of them is low emission, which in Poland will not be reduced without significant financial support. It should be noted that this support should not only concern enterprises and institutions, but should also be intended for households. From 1 August 2018, the governmental program Clean Air has been launched for individuals with ownership. Co-financing of a normal thermo-modernization (home insulation, window change, replacement of old, high pressure, installation and installation, installation of boilers and heating devices). The program will last until 30 June 2029 with a total of PLN 103.0 billion. Focuses on facts and financial requirements. The goal of the program is to improve efficiency over the term of the contract with single-family housing.

\section{REFERENCES}

1. Act of 27 April 2001. Environmental protection law (Journal of Laws of 2013 r., Pos. 1232 with later change).

2. Bohringer Ch., Rutherford T. F., Transition towards a low carbon economy: A computable general equilibrium analysis for Poland [w] Energy Policy 55, 2013.

3. Burchard - Dziubińska M., Availability and quality of statistical data indispensable for low-emission development strategies in local government units [in] Optimum Economic Studies, nr 3(69),2014.

4. Constitution of the Republic of Poland of 2 April 1997 (Journal of Laws 78, Pos. 483).

5. Detailed description of priority axes of the Regional Operational Program of the Lower Silesian Voivodship2014-2020, 2015. 
6. Detailed Description of the Priority Axes of the Regional Operational Program - Lubusz 2020, November 2018.

7. Detailed Description of the Priority Axes of the Regional Operational Program for the West Pomeranian Voivodeship 2014-2020 Version 25.0-17 of October 2017.

8. Directive 2009/28 / EC of the European Parliament and of the Council of 23 April 2009 on the promotion of the use of energy from renewable sources, amending and subsequently repealing Directive 2001/77/EC and 2003/30/WE (Journal of Laws UE L 09.140.16).

9. Dzikuć M., Problems associated with the low emission limitation in Zielona Góra (Poland): Prospects and challenges [in] Journal of Cleaner Production 166 (2017).

10. European Commission, Action plan leading to the transition to a competitive low-carbon economy by 2050, Brussels, 2011a.

11. European Commission, Roadmap to a low-carbon economy by 2050 , Brussels, $2011 \mathrm{~b}$.

12. European Commission, Our life insurance and our natural capital - EU strategy for the protection of biodiversity for the period up to 2020, Brussels, $2011 \mathrm{c}$.

13. European Commission, Horizon 2020 - Framework Program for Research and Innovation, Brussels, 2011d.

14. European Commission Europe 2020. A strategy for smart, sustainable and inclusive growth, Brussels, 2010.

15. European Commission, EU Climate and Energy Package, Brussels, 2007.

16. European Commission,, A Sustainable Europe for a Better World: The EU Sustainable Development Strategy, Brussels, 2001.

17. European Parliament resolution of 15 March 2012 on an action plan leading to the transition to a competitive low-carbon economy since do $2050 \mathrm{r}$. (2011/2095(INI).

18. http://misja-emisja.pl/z dnia 01.12.2018 r.

19. Jankiewicz S., Basics of economic policy, AE in Poznan, Poznan, 2006.

20. Jankiewicz S., Low-carbon economy as the basis for the region's development [in] Social Inequalities and Economic Growth, R 49 (1/2017).

21. Jeżowski P., Climate-energy policy as crucial barrier to sustainable development in Poland [in] Optimum. Economic Studies, 88/2017.

22. Krawiec F. (red.), Renewable energy sources in the light of world energy crisis. Chosen problems, Warszawa, 2010

23. Kyoto Protocol to the United Nations Framework Convention on Climate Change, done at Kyoto on 11 December 1997 (Journal of Laws of 17 October 2005). 
24. Ministry of Economy, Project: National Program for the Development of Low-Emission Economy, Warsaw, 2015.

25. Ministry of Economy, assumptions of the National Program for the Development of Low-emission Economy, Warsaw, 2011.

26. Ministry of the Environment,, Strategy for Sustainable Development of Poland until 2025. Guidelines for ministries, Warsaw, 1999.

27. Pająk K., Kvilinskyi O., Fasiecka O., Miśkiewicz R., Energy security in regional policy in Wielkopolska region of Poland, Economics and Environment, 2(61), 2017.

28. Piontek, F., Economic mechanisms used in environmental protection and the category of effectiveness [in] Problems of Ecology, R. 3, nr 6, 1999.

29. Sadlok R., (red.), Preventing low emissions in areas of compact residential buildings, National Fund for Environmental Protection and Water Management, Association for energy efficiency and development of renewable energy sources, HELIOS", Cracov 2014.

30. United Nations Conference on Climate Change COP 19, The system of financing environmental protection in Poland, Warsaw 2013 "S.4.

31. Węglarz A., What is meant by the low-emission economy, the National Agency for Energy Conservation S.A., Warsaw, 2013.

\section{GOSPODARKA NISKOEMISYJNA - EWOLUCJA CZY KONIECZNOŚĆ}

\section{Streszczenie}

Gospodarka niskoemisyjna służy zapewnieniu korzyści: ekonomicznych, społecznych i środowiskowych płynących $\mathrm{z}$ działań zmniejszających emisje zanieczyszczeń. Wdrażanie gospodarki niskoemisyjnej w Polsce wynika z potrzeby dokonania redukcji emisji gazów cieplarnianych i innych zanieczyszczeń powietrza przy jednoczesnym zmniejszeniu udziału węgla $\mathrm{w}$ wytwarzaniu energii, wprowadzaniu innowacyjnych technologii i poprawie efektywności energetycznej oraz wzroście poziomu życia społeczeństwa. Jest to trudne zadanie ze względu na duże wykorzystanie węgla w wytwarzaniu energii. Celem artykułu jest pokazanie celów tworzenia Planów Gospodarki Niskoemisyjnej przez jednostki samorządowe na szczeblu lokalnym oraz ich wykorzystanie w ubieganiu się o środki finansowe w perspektywie finansowej 20142020.

Słowa kluczowe: gospodarka niskoemisyjna, plany gospodarki niskoemisyjnej 